\title{
Franchising And The Society: The Case Of Franchising In The Hotel Industry
}

\author{
Ramon Diaz-Bernardo, PhD, Instituto de Empresa Business School, Madrid - Spain
}

\begin{abstract}
Franchising is a major trend in the hotel industry. Despite the fact that almost two thirds of branded hotels in the US are franchised there is a distinct lack of empirical research on franchising in the hospitality industry. In this article we have reviewed one of the most relevant lines of research in franchising literature usually referred as franchising and the society, and we have concentrated on analyzing one of the most controversial issues in this line of research: the territorial rights in hotel franchising contracts. The paper identifies the main sources of conflict when dealing with territorial rights in hotel franchising contracts.
\end{abstract}

Keywords: Franchising, Hotels, Franchisor, Franchisee.

\section{INTRODUCTION}

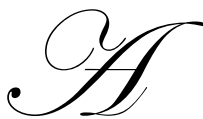

franchise system is a collaboration agreement between two independent business parts, the franchisor and the franchisee, whereby the franchisor allows the franchisee the right to use his brand name, products and services, and specific know-how in exchange for direct or indirect payments to the franchisor by the franchisee. In other words, the franchise system "consists of multiple organizations that are legally independent, economically interdependent, and operationallyindistinguishable to consumers" (Parsa 1996).

The success of the franchise system is reflected in its spectacular growth figures. In the US where the franchising system began in the early $20^{\text {th }}$ century, there are over 3,000 companies involved in franchising, accounting for over $10 \%$ of GDP and an estimated $30 \%$ of retail sales.

In the hotel industry the franchising system is also constantly growing. According to Mintel Marketing Intelligence 2005 International Hotel Industry Report, 67\% of US room capacity is branded, mainly through franchise contracts. Almost all the big US hotel chains are involved in franchising, eighteen of the top twenty US hotel brands use franchising, so franchising has become a hot topic of interest in the hotel industry. The situation is different in Europe where the franchising system is less popular and the hotel chains still prefer to grow via leasing or management contracts instead of franchising.

Asked about the different behavior of the European and the US hotel markets concerning franchising, our two European experts expressed similar opinions. Mr. Jordi Frigola, Senior Vice President Jones Lang LaSalle Europe, explained that "In Europe the level of concentration and branding is very low compared to the US. Most of the European hotel chains prefer the leasing contracts. And also the investors prefer a lease contract with no risks than hands on franchising contracts." Mr. Bernardo Cabot, Director of Expansion European Division of Sol Melia, on a similar vein added that "There are three potential barriers to the development of franchising in the European hotel industry: (1) a lack of potential franchisees with both the necessary skills and the financial resources needed; (2) a great concern about the quality standards of the potential franchisees and how to enforce the chains quality standards in the franchisee's property: (3) litigation and other legal issues involved in the franchise contract".

In parallel with the rapid expansion of franchising, there is a growing interest among academics and practitioners in studying the franchise system. The literature on franchising has followed three major lines of research: franchising and the society, creating franchise systems and managing a franchise system. In this paper we 
will concentrate on analyzing the line of research known as franchising and the society. We will do that by reviewing the relevant literature on the subject and by confronting what the theiry says with the opinions of our panel of experts and also with the empirical information collected from public sources of information regarding the hotel industry.

\section{FRANCHISING AND THE SOCIETY}

Within the line of investigation referred to as "franchising and the society" researchers have looked at the franchising issue from the viewpoint of public policy and considered the effect of franchising on the society as a whole. In her seminal article Hunt (1977) explained what she called the "promise" of franchising, that is the purported benefits of franchising to society in general, to franchisees, and to franchisors. The research question in this case is whether, in general, franchising offers any kind of benefit to the society.

Franchising advocates maintain that society in general should benefit from franchising because of the lower failure rates for franchised business compared to independent ones. The purported lower failure rates result in a better assignment of economic resources and so a benefit to society in general.

Business failure is of great significance to society and prospective entrepreneurs; the US Dept. of Commerce data suggest that $67 \%$ of the new business discontinued in the first five years. On the other hand, the alleged lower failure rates are one of the main selling arguments for attracting potential franchisees to the franchise system. But, are the failure rates really lower? The empirical evidence is not clear. Back in 1977 Hunt reported that "(They) could find no solid evidence that franchisees have either a better or poorer chance for business survival than do similarly qualified independent entrepreneurs".

Published investigations have reported mixed results to the question of franchising failure rate. Ayling (1988) found that franchising has a lower failure rate than that of independent business, but Bates (1995) reported opposite evidence, finding that failure rates among franchisees were higher than among independent businesses. Other empirical studies have found that the failure rate varies by industry and that franchisees of older chains had higher failure rates.

Despite the unclear evidence, many people assume that franchisors are selling a formula for success, and the general perception is that franchisees have more chances of survival than independent businesses, as explained by Fulop and Forward (1997) "despite the lack of convincing statistics that franchising is less risky for franchisees than operating an independent business, it has been pointed out that banks are prepared to offer preferential loans to franchisees based on their experience that franchising lowers the risk of failure."

\section{FRANCHISING AND THE SOCIETY: THE CASE OF THE HOTEL INDUSTRY}

In the hotel industry the situation is mainly the same, it is not clear whether the failure rates for franchised hotels is lower than that of independent hotels. Despite the fact that according to the Dun \& Bradstreet Corporation reports, the lodging industry has consistently maintained lower failure rates than the average US business failure rates, there is no clear evidence of the effect of franchising on the propensity to failure or survival. In a study of hotel failure rates in the US, Ingram and Baum (1997) found that the chances of survival were higher for chain affiliated hotels than for independent hotels.

In the restaurant industry, Parsa et.al. (2005) found that among franchised chains the failure rate was 57 percent over the first three years of operation, and among independent restaurants the rate was 4 percent higher -61 percent. Despite the reported empirical evidence, in the hotel industry, as in the rest of the businesses, the general perception is that the failure rate of the franchised business is lower than the one of an independent operation.

As one hotel franchisee pointed out in a conversation with the author: "I don't know if the failure rate is higher or lower, but having a brand behind you gives you some advantages over the independent operator". It seems that there is an agreement in the hotel industry about the importance of the brand to the success of a franchised hotel. 
As Jordi Frigola, Senior Vice President Jones Lang LaSalle Europe pointed "In my experience valuing hotels, the fact that the hotel has a franchised contract is not what is important, what most influences the value of the property is the effect of the brand on the property's results, (..), being a franchisee you are going to pay the franchisor brand a $8-10 \%$ of your revenues, $(\ldots)$, there are brands that really payback, but there are many others that do not, (...), I have seen franchising brands that only provided a 5\% of the property's reservations, that clearly does not payback the fees and royalties paid to the brand."

Other issues that come under the franchising and the society literature are: the amount of information the franchisor is obliged to give a potential franchisee, the termination provisions in the franchise contract, legal aspects and court interpretations of franchise contracts, the effect of franchise contracts on free competition, the pricing and product policy imposed by the franchisor- usually the franchisor require the franchisee to maintain a specified price policy and the franchisee can only sell goods or services approved by the franchisor-, and the territorial rights in the franchise contracts .

Of the topics listed above, one has drawn major interest in the franchising hotel industry that is the definition of exclusivity sales areas in the franchise contracts and the impact when the franchisor opens a competingbrand or same-brand hotel in the franchisee's trading area.

Interestingly most of the franchising hotel chains do not grant exclusivity rights in their franchising contracts, and this is often a cause of conflict between franchisor and franchisee, as it is illustrated in the case of Choice Hotels (Khana, 1995): "The franchise contract provides no territorial rights or other promises of market allocation and did not restrict the franchisor from engaging in any business activity at any location other than the franchisee's hotel, regardless of proximity to the hotel... Though the opening of another Choice franchise near a particular franchisee's hotel did not constitute illegal action on the basis of the contract, some franchisees felt betrayed by such action".

In a study conducted by Kalnins (2005) he found that when franchisors approve new same-brand hotels in the vicinity of existing hotels, these new hotels do indeed cannibalize the incumbents' revenue, causing a loss of almost 3 percent of the typical hotel mean revenues, still, a competing brand's entry causes lower revenue loses and there is no impact when company-owned chains open same-brand properties. So, there is a reason for franchisees to complain, even when the impact of a same-brand opening does not seem to be great enough to risk the franchisees' survival, the franchisor must consider this effect.

What franchising hotel chains are doing to prevent conflicts is informing existing franchisees of applications for new franchises that could impact their hotels, and giving them an opportunity to contest such applications. That is the case of Choice Hotels, as explained by Joseph Lavin, ex Senior Vice President Development Choice Hotels: "There are two ways in which objections are raised: First, the franchisee simply writes a letter indicating objection; second, the franchisee files a formal objection and fills a comprehensive form indicating reasons why impact exists. Franchisees are also allowed to retain one of several entities that will conduct an impact study for them. Of all new deals, about $14 \%$ generate a formal objection form franchisees. Of these, $30 \%$ go to the study process, and we (the franchisor) prevail in $65 \%$ of the cases. However, in addition to that, we turn down plenty of applications, often on the grounds of impact. In fact, of the deals made by competing chains, 35\% are such that we can't even enter the negotiations, since it's an obvious impact situation".

In a later conversation with the author, Mr Lavin explained that in his experience with Marriott franchisees, the situation was different: "At Marriott, we had about 300 franchisees, at Choice there were more than 1,500, and even when neither Choice nor Marriott gives territorial rights, Marriott experienced less conflicts with their franchisees than Choice in similar situations, ..., Marriott works like a family with its franchisees. Marriott prefers a relatively small number of franchisees, doing multiple deals, which makes it easier to develop trust and have less conflict like the typical territory claim, but territory rights are always a source of conflict for any franchising hotel chain".

Therefore it seems that the territorial rights will continue to be an issue of conflict between franchisors and franchisees, specially considering that the royalties that the franchisor receives from the franchisee are a percentage 
of sales, not profit, so the economic incentive for the franchisor is to give as much licenses as he can to increase sales volume even when franchisees profits may be exposed.

\section{SUMMARY}

Franchising is a major trend in the hotel industry. Despite the fact that almost two thirds of branded hotels in the US are franchised there is a distinct lack of empirical research on franchising in the hospitality industry. The line of investigation referred to as franchising and the society includes a topic that is highly relevant to the hospitality industry: territorial rights in franchised contracts. The hospitality industry is one of the few industries where the franchisor will rarely grant exclusivity in the franchising contract. All the hotel industry experts contacted by the author noted that territorial rights are a source of constant conflict between franchisor and franchisees. How to manage this source of conflict is still an unsolved question in the industry and is a very attractive research question for future investigations.

\section{AUTHOR INFORMATION}

Ramón Díaz-Bernardo, Professor of Marketing - IE Business School. An expert in strategic marketing, some years ago Professor Ramón Diaz-Bernardo decided to extend his field of research to tourism and hotel marketing strategy. Professor Diaz-Bernardo holds a degree in Engineering from Universidad de Oviedo (Spain), an MBA from ESDEN Business School (Madrid) and he is a Doctor in Business Administration (Ph.D.) from IESE Business School (Barcelona).

He is an active member of the Academy of Marketing and the American Marketing Association, where he is a regular contributor at their annual meetings. Furthermore he is a visiting professor at Cornell University (USA), Nanyang Business School (Singapore), and Reykjavik University (Iceland), among other international business schools.

\section{REFERENCES}

1. Ayling, D. (1988), "Franchising in the UK", Quarterly Review of Marketing, Vol. 13, No. 4, pp. 19-24

2. Bates, T. (1995), "Analysis of Survival Rates Among Franchise and Independent Small Business Statups", Journal of Small Business Management, Vol. 33 (2), pp. 26-36

3. Fulop C. and Forward, J. (1997), "Insights into Franchising: A Review of Empirical and Theoretical Perspectives", The Services Industries Journal, Vol. 17, No. 4

4. Hunt, S. D. (1977), "Franchising: Promises, Problems, Prospects", Journal of Retailing, Vol. 53 (3), pp. 7184

5. Ingram, P and Baum, J.C. (1997), "Chain Affiliation and the Failure of Manhattan Hotels 1898-1980", Administrative Science Quarterly, Vol. 42, pp. 68-102

6. Kalnins, A. (2005), "The Effect of New Hotels and Brand Conversions on Revenues of Existing Hotels", Center for Hospitality Research Reports, Cornell University

7. Khanna, T. (1995), “Choice Hotels International, 1995”, Harvard Business School Case, HBS Publishing, Boston, MA

8. Parsa, H.G. (1996), "Franchisor-Franchisee Relationship in Quick-Service-Restaurant Systems," Cornell Hotel and Restaurant Administration Quarterly, Vol. 37 (3), pp. 42-50

9. $\quad$ Parsa, H.G.; Self, J.T.; Njite, D.; and King, T. (2005), "Why Restaurants Fail”, Cornell Hotel and Restaurant Administration Quarterly, Vol. 6, pp. 304-322 